\title{
Die gesinsdinamika van pastoriegesinne in die drie Afrikaanse kerke
}

\author{
C.A Venter \& G.E. Grobler \\ Dept. Psigologie \\ Potchefstroomse Universiteit vir $\mathrm{CHO}$ \\ POTCHEFSTROOM
}

\begin{abstract}
The divorce rate among white South Africans is disturbing. There are indications of a growing divorce rate also among families of ministers of religion. Little scientific research seems to be available on the marital and family life of ministers, especially in the RSA.

The aim of the research on which this article is based was to determine whether significant differences occur between the marital and family dynamics of ministers' families and the families of parishioners. Thirty clerical couples and some of their children $(N=96)$ and thirty parish couples and some of their children $(N=95)$ were involved in the research. Six measuring instruments were applied in evaluating the families.

The results seem to indicate that the clerical couples experience their marital dynamics significantly better than the other married couples on 12 of the 19 dimensions which were evaluated. With regard to family functioning the ministers' families performed significantly better than the parish families on six of the 14 dimensions. There are indications, however, that the clerical couples represented their marital and family functioning in a more positive light than was the case in reality. Therefore no really valid interpretations can be made from the results.
\end{abstract}

\section{Inleiding}

Die egskeidingsyfer van die RSA wek kommer. 'n Ontleding van die egskeidingsyfer toon dat daar gedurende die vroeë tagtigerjare jaarliks gemiddeld ongeveer 45,000 blanke huwelike bevestig is en in dieselfde tydperk is daar gemiddeld ongeveer 17,000 egskeidings toegestaan waarby gemiddeld ongeveer 21,000 minderjarige kinders betrokke was (Venter, 1988:2-3). Dit is verder kommerwekkend dat daar gedurende die tydperk 'n geleidelike toename in die egskeidingsyfer was (Venter, 1988:2). 
Dit blyk dat die groeiende egskeidingsyfer ook by pastoriegesinne voorkom Odendal (1984) het in sy navorsing verwys na die groeiende egskeidingsyfer by pastoriegesinne van die Nederduitse Gereformeerde Kerk. Die Algemene Kommissie van die Nederduitsch Hervormde Kerk het in 1986 opdrag gegee dat pastoriehuwelike ondersoek moet word. Die tendens wat in die RSA voorkom, wek ook intemasionaal kommer - soos blyk uit verskeie buitelandse publikasies (Bouma, 1979; Mace \& Mace, 1980)

Die vraag kan gevra word waarom daar so 'n toename in huweliksprobleme en egskeidings in pastorieë is. Is dit vanweë druk van die eietydse samelewing waaraan die meeste gesinne onderwerp is, of is daar moeilikhede wat pastoriegesinne in besonder kwesbaar maak? Faber (198?(a):9-13) verwys onder meer na die moontlike invloed van sekularisasie, emansipasie, soeke na nuwe lewenspatrone, kulturele en kerklike tradisie. Een van die grootste probleme wat pastoriegesinne moontlik ondervind en wat verreikende gevolge op hulle gesinsinteraksie kan hê is dat hulle "... gesitueerd is 'in een glazen huisje' ... behoren niet alleen aan zichself toe, ze behoren tegelijk toe aan de gemeente" (Miethner \& Miethner, 1978:410). Die pastoriegesin het gevolglik 'n gebrek aan privaatheid en die sogenaamde visbaksindroom kom voor. Onrealistiese rolverwagtings word dikwels aan die pastoriegesin gestel en dit plaas druk op die pastoriehuwelik en die gesinslewe (MacCullough, 1983:63-76).

Dit blyk uit die literatuur dat daar talle publikasies verskyn het oor sekere aspekte van die predikant en sy gesin. Daar is byvoorbeeld publikasies oor die predikant en sy ampswerk (Guynes, 1979; Anderson, 1985), uitbranding by predikante (Rediger, 1982; Odendal, 1984), die rol van die predikantsvrou (Douglas, 1965; Niswander, 1982) en kinders uit pastoriegesinne (Stevenson, 1982). Dit is opvallend dat daar min wetenskaplike navorsing oor die huweliks- en gesinslewe van predikante gerapporteer is.

In hierdie navorsing wat gerapporteer word, is daar talle verwysings na aspekte van die pastoriegesinne se funksionering wat problematies sou wees. Grobler (1988:85) is egter van mening dat die beskikbare literatuur oor pastoriegesinne veral fokus op die probleemareas van die gesinne. Volgens haar (Grobler, 1988: 85 ), kan hierdie tendens moontlik toegeskryf word aan die besorgdheid wat heers oor die toenemende problematiek in dié gesinne

Vanweë die afwesigheid van navorsing, veral in die RSA, en die feit dat bestaande literatuur veral negatief rapporteer oor die huweliks- en gesinsverhoudinge van pastoriegesinne, het die navorsingsvraag ontstaan of die huweliks- en gesinsfunksionering van pastoriegesinne verskil van dié van ander persone. Die doel van hierdie navorsing (Grobler, 1988) was dus om te bepaal of daar bedui- 
dende verskille is tussen die huweliks- en gesinsfunksionering van pastoriegesimne en gesimne van gemeentelede in die drie Afrikaanse kerke.

Die navorsing is gedoen vanuit 'n sisteemteoretiese raamwerk en daar is gefokus op die gesin as geheel. Hierdie benadering is gevolg omdat die meeste van die reeds beperkte navorsing wat oor pastoriegesinne bestaan, slegs toegespits was op sekere fasette van dié gesimne se funksionering.

\section{Die navorsing}

\subsection{Navorsingsontwerp}

'n Ex post facto-navorsingsontwerp is gebruik.

\subsection{Proefpersone}

Die populasie wat gebruik is in hierdie navorsingsprojek is pastoriegesinne en gemeentelede van die drie Afrikaanse kerke, naamlik die Nederduitse Gereformeerde Kerk, die Nederduitsch Hervonnde Kerk en die Gereformeerde Kerke in die Potchefstroom-Klerksdorpgebied. Kriteria waaraan al die gesinne moes voldoen was die volgende: albei ouers moes nog leef en die gesin moes minstens oor een skoolgaande kind beskik.

Groep A (die pastoriegesinne) se proefpersone is betrek deur bekendstellingstukke van die navorsing aan die 46 predikante van die streek te stuur. Van die persone wat voldoen aan die gestelde kriteria en hulle bereid verklaar het om deel te neem, is die eerste 30 ingesluit in die proefgroep.

Om groep B (gesinne van gemeentelede) se proefpersone te betrek, is die predikante wat in groep A opgeneem is, versoek om in hulle gemeentes die gesimne te identifiseer wat voldoen aan die gestelde kriteria. Van die 243 gesinne wat sodoende geidentifiseer is, is 30 gesinne geselekteer volgens die loterymetode (Smit, 1985:184). Daar is dus gebruik gemaak van 'n eenvoudige ewekansige steekproefstrategie. In gevalle waar die gesinne nie beskikbaar was of bereid was om deel te neem nie, is addisionele gesinne geselekteer.

Die persone in groep A was gemiddeld 16,6 jaar getroud met 'n spanwydte van 8 tot 28 jaar. Van die 30 vrouens was 20 huisvroue. Die ander 10 het bestaan uit professionele persone en staatsamptenare. Van die 105 kinders in die steekproef was 36 ouer as 12 jaar en nog skoolgaande. Die 36 kinders is by die navorsing betrek, want een van die vraelyste (die FAD) vereis dat persone ouer as 12 moet wees. Daar was gemiddeld 3 kinders in die gesinne. In die groep was 14 gesinne lidmate van die Nederduitse Gereformeerde Kerk, 8 gesinne van die Nederduitsch Hervormde Kerk en 8 gesinne van die Gereformeerde Kerke 
Die persone in groep B was gemiddeld 17,7 jaar getroud met 'n spanwydte van 7 tot 34 jaar. Die meeste van die vaders in die groep was staatsamptenare en die res was professionele persone. Twaalf van die vrouens was huisvrouens en die res het bestaan uit staatsamptenare en professionele lui. Van die 87 kinders in die steekproef wat betrek is by die navorsing, was 35 ouer as 12 en nog skoolpligtig. Daar was gemiddeld 3 kinders in die gesinne. In die groep was 8 gesinne lidmate van die Nederduitse Gereformeerde Kerk, 9 gesinne van die Nederduitsch Hervormde Kerk en 13 gesinne van die Gereformeerde Kerke.

\subsection{Meetinstrumente}

Die gesinsdinamika van die 60 gesinne is geëvalueer met meetinstrumente wat in Afrikaans vertaal is, naamlik:

- Enriching \& Nurturing Relationship Issues, Communication \& Happiness (ENRICH) (Olson et al., 1985a).

- Personal Assessment of Intimacy in Relationships (PAIR) (Schaefer \& Olson, 1981).

- $\quad$ Primary Communication Inventory (PCI) (Navran, 1967).

- McMaster Family Assessment Device (FAD) (Epstein et al., 1983).

- Family Adaptability and Cohesion Evaluation Scale (FACES III) (Olson et al., 1985b).

- Family Crisis Oriented Personal Evaluation Scale (F-Copes) (McCubbin et al., 1985).

Eersgenoemde drie meetinstrumente meet die huweliksverhouding van die egpare terwyl laasgenoemde drie die gesinsfunksionering meet.

Daar is slegs van oorsese meetinstrumente gebruik gemaak vanweë die afwesigheid van geskikte Suid-Afrikaanse toetse. Die skale is gekies omdat die opstellers daarvan gerapporteer het dat hulle oor bevredigende psigometriese eienskappe - betroubaarheid en geldigheid - beskik. Aangesien die toetse nie gestandaardiseer is vir die Suid-Afrikaanse toestande nie, is slegs die onverwerkte punte van elke toets gebruik by die interpretasie van die gegewens. Die betroubaarheidskoëffisiënt (Cronbach alfa) van elke meetinstrument is ook bepaal.

\subsection{Prosedure}

$\mathrm{Na}$ die steekproeftrekking is elke gesin afsonderlik besock en by hulle huise getoets. Die vaders en die moeders het al ses die meetinstrumente ingevul, maar die kinders ouer as 12 het slegs die drie gesinskale ingevul, dit wil sê die FAD, FACES III en F-Copes. Die t-toets vir onafhanklike groepe is by al die meet- 
instrumente gebruik om vas te stel of daar beduidende verskille is tussen die pastoriegesimne en die gesimne van gemeentelede. Die beduidendheid op die 5\%vlak is gebruik vir die aanvaarding of verwerping van hipoteses.

\section{Resultate en bespreking}

\subsection{Huwelikfunksionering}

\subsubsection{ENRICH}

Die egpare van die pastoriegesinne het hulle huweliksverhouding statisties beduidend beter ervaar as die egpare van die ander groep gesimne op agt van die 12 dimensies wat deur die vraelys geëvalueer is (vergelyk Tabel 1). Die dimensies wat geëvalueer is sluit die volgende in: distorsie van ideale, huweliksbevrediging, persoonlikheidsaangeleenthede, konflikhantering, seksuele verhouding, kinders en die huwelik, familie en vriende, en geloofsoriëntasie.

Uitgesonderd die subskaal familie en vriende, met 'n Cronbach alfa-betroubaarheidskoëffisiënt van 0,57 was die ander subskale se betroubaarheidskoëffisiënte bevredigend tot goed. Ses subskale se betroubaarheidskoëffisiënte was bo 0,76 en een skaal, naamlik kinders en die huwelik was 0,70 (Grobler, 1988:185).

Vanweë die rasionaal van die subskale wat bogenoemde dimensies evalueer, sou dit gestel word kon dat die egpare van die pastoriegesinne hulle huweliksverhouding meer bevredigend ervaar as die egpare van die gemeentelede ten opsigte van die volgende aspekte: die neiging om persoonlike vrae op 'n normaal aanvaarde wyse te beantwoord; die globale siening van hulle huwelikstevredenheid; die mate van tevredenheid wat hulle ervaar jeens hulle lewensmaats se persoonlikheidstrekke; openlieid om konflik te identifiseer en bevredigend op te los; uitdruk van affeksie, vermoë om oor seksuele aangeleenthede te praat en hulle houding jeens seksuele gedrag; bewustheid van hulle kinders se impak op die huweliksverhouding; tevredenheid met luulle rolle as vader en moeder en aanpasbaarheid in luulle dissipline, en siening in verband met die betekenis en belangrikheid van hulle godsdienstige oortuigings op die huwelik.

Die feit dat die egpare van die pastoriegesinne die neiging geopenbaar het om die vrae op 'n sosiaal aanvaarbaarder wyse as die ander groep se egpare te beantwoord (op die subskaal distorsie van ideale), bemoeilik die interpretasie van die meetinstrument se resultate. Die moontlikheid bestaan dat die werklike verskille tussen die twee groepe egpare kleiner kan wees as wat aangetoon is, en dat daar selfs geen verskille kan wees nie.

Indien dit wel so is dat die pastoriegesinne se egpare op bogenoemde dimensies beter daaraan toe is as die van gemeentelede, is die gunstige beeld teenstrydig \begin{tabular}{ll}
\hline Koers 59(2) $199+: 275-292$ & 279
\end{tabular} 
met sommige aannames wat in die literatuur gemaak word. Miethner en Miethner (1978:411-412) meld dat konflikhantering in pastoriehuwelike dikwels op die lange baan geskuif word omdat predikante betrokke is by ander mense se probleme en dan sy eie vermy. Presnell (1977:274) en Mace en Mace (1980:37) meen dat die spanning wat deur die tradisionele rolmodel teweeggebring word ook probleme tussen die huwelikspaar kan veroorsaak, onder meer in hulle seksuele verhouding. Volgens Faber (198?b:105) en Smuts (1986:60) kan die predikant se arbeidsvermoeidheid daartoe lei dat hy weinig energie het vir sy gesin en dat dit selfs 'n negatiewe uitwerking kan hê op die dissipline in die gesin. Sekere skrywers wys ook daarop dat die gebrek aan privaatheid wat deur pastoriegesinne ervaar word, kan lei tot huweliksprobleme (Bouma, 1979:18; Faber, 198?a:20). Kruijne (198?:33) meld dat die heimlike superioriteitsgevoel wat soms by predikante voorkom, die sogenaamde 'ek-is-God-kompleks', ook spanning en konflik in die huwelikslewe van die predikant kan veroorsaak.

Die feit dat die egpare in die pastoriegesinne moontlik beter daaraan toe is as die ander egpare ten opsigte van hulle geloofsoriëntasie is te verstane. Dit kan moontlik wees vanweë die sterk eenheidsgevoel wat hulle beleef ten opsigte van hulle gedeelde geloofsuitlewing en diensbaarheid as pastoriepaar (vergelyk 3.2.2).

Die vier dimensies waarop daar nie beduidende verskille tussen die twee groepe egpare gevind is nie was die subskale se betroubaarheidskoëffisiënte kommunikasie $(0,78)$, finansies $(0,72)$, vryetydsbesteding $(0,32)$ en gelykmakende rolle $(0,57)$ (Grobler, 1988:185, 206). Daar is dus nie verskille tussen die egpare ten opsigte van hulle gevoelens en houding oor die kommunikasie en hulle verhouding, houding en besorgdheid oor die wyse waarop die finansiële aangeleenthede van die gesin beheer word, voorkeure ten opsigte van vryetydsbesteding, en hulle gesindheid teenoor verskillende huweliks- en gesinsrolle nie.

\subsubsection{PAIR}

Die resultate het getoon dat die egpare van die pastoriegesinne hulle intimiteit op drie van die vyf intimiteitsubskale beduidend beter beleef het as die ander groep egpare (vergelyk Tabel 2). Die drie subskale was emosionele, seksuele en intellektuele intimiteit.

Die betroubaarheidskoëffisiënte van die drie skale was goed, naamlik $0,88,0,80$ en 0,80 onderskeidelik (Grobler, 1988:188).

Die interpretasie van die meetinstrument se resultate is, soos in die geval van ENRICH, ook bemoeilik omdat die egpare in die pastoriegesinne op die sosiale gewensdheidskaal statisties beduidend beter gevaar het as die egpare bestaande uit gemeentelede se gesinne. Die betroubaarheidskoëffisiënt van die skaal was 
goed $(0,87)$ (Grobler, 1988:188). Die egpare van die pastoriegesinne het dus ook op die vraelys die vrae op 'n sosiaal aanvaarbaarder wyse ingevul as die ander groep egpare. Die moontlikheid bestaan dus dat die verskille tussen die twee groepe egpare op bogenoemde drie intimiteitsdimensies kleiner is as wat aangetoon is of dat die verskille selfs nie bestaan nie.

Indien daar wel verskille is, impliseer dit dat die egpare van die pastoriehuwelike beter daaraan toe is as die ander egpare ten opsigte van hulle vermoë om gevoelens te deel in 'n nie-verdedigende atmosfeer, die belewing en betoning van algemene affeksie, aanvaarding, fisieke nabyleid en/of seksuele aktiwiteit en om openlik te kan praat oor sake van die dag.

Die twee subskale waarop daar nie verskille tussen die groepe aangetref is nie, en die betroubaarheidskoëffisiënte van die subskale, was sosiale intimiteit $(0,40)$ en ontspanningsintimiteit $(0,64)$ (Grobler, 1988:188, 208). Daar is dus moontlik nie verskille tussen die groepe ten opsigte van hulle belewing van gemeenskaplike vriende en hulle gemeenskaplike betrokkenheid by algemene vryetydsbesteding nie.

Alhoewel ENRICH huwelikstevredenheid evalueer en PAIR intimiteit, is daar ooreenkomste in die bevindinge van die twee skale. Albei skale het aangetoon dat die pastorie-egpare hulself op sekere dimensies beter evalueer as die ander egpare.

\subsubsection{PCI}

Geen beduidende verskille tussen die twee groepe egpare is op dié meetinstrument gevind nie (vergelyk Tabel 3). Die betroubaarheidskoëffisiënt van die skaal was goed, naamlik 0,88 (Grobler, 1988:189). Daar bestaan nie verskille tussen die twee groepe egpare ten opsigte van hulle kommunikasievaardighede nie. Die $\mathrm{PCl}$ se resultate stem dus ooreen met die resultate van die dimensie kommunikasie op ENRICH waar daar ook geen verskille tussen die groepe aangetoon is nie.

Die resultate van ENRICH, PAIR en PCl het dus getoon dat die pastorie-egpare hulle huweliksverhouding beduidend beter ervaar het as die gemeentelike egpare op 12 van die 19 dimensies wat geëvalueer is. Soos aangetoon, word die interpretasie van die bevindinge bemoeilik ondat die pastorie-egpare hulle verhoudings, bewus of onbewus, beter wou voordoen as wat werklik die geval is. Vanweë dié verskynsel kan daar geen geldige afleidings gemaak word oor die verskille wat daar bestaan tussen die huweliksverhouding van die twee groepe egpare nie. 


\subsection{Gesinsfunksionering}

\subsubsection{FAD}

Die resultate van die meetinstrument het getoon dat die gesinslede van die pastoriegesinne hulle gesinsfunksionering statisties beduidend beter ervaar het as die gesinslede van die gemeentelede op ses van die sewe dimensies wat deur die FAD geëvalueer is (vergelyk Tabel 4). Die dimensies is: probleemoplossing, kommunikasie, affektiewe responsiwiteit, affektiewe betrokkenheid, gedragskontrole en algemene funksionering.

Die Cronbach alfa-betroubaarheidskoëffisiënt van die subskale waarop beduidende verskille tussen die groepe aangetref is, was kommunikasie $(0,72)$, affektiewe responsiwiteit $(0,69)$, algemene gesinsfunksionering $(0,78)$, probleemoplossing $(0,62)$, affektiewe betrokkenheid $(0,61)$ en gedragskontrole $(0,51)$ (Grobler 1988:178). Eersgenoemde drie skale se betroubaarheid kan as bevredigend beskou word terwyl die subskaal gedragskontrole onbevredigend is. Die verskille wat op bogenoemde subskaal tussen die twee groepe gesinne gevind is, moet daarom versigtig geïnterpreteer word

Vanweë die rasionaal van elk van die genoemde dimensies se subskale, sou dit gestel kon word dat die gesinslede van die pastoriegesimne, in teenstelling met die gesinslede van die gemeentelede, meer sistematies en doelgerig optree tydens probleemoplossing; duideliker en meer direk met mekaar kommunikeer; ' $n$ wyer spektrum emosies meer toepaslik ervaar; sinvoller emosionele verhoudings met mekaar handhaaf; duideliker standaarde en reëls het vir hulle optredes en in die algemeen as gesinne beter funksioneer.

Hierdie bevindinge kan egter nie sonder meer as geldig beskou word nie, en wel om twee redes. Alhoewel daar statisties beduidende verskille tussen die twee vergelykingsgroepe bestaan, is die werklike verskille relatief klein (vergelyk die gemiddeldes op die FAD). Dit moet verder ook in ag geneem word dat pastorieegpare die vrae oor hulle huweliksverhouding op sosiaal aanvaarbare wyse beantwoord het, en dit heel moontlik ook op die gesinskale gedoen het. 'n Verdere ontleding van die FAD se resultate is gedoen en dit het geblyk dat die kinders in die twee groepe ( $N=36$ en $N=35$ onderskeidelik) geen beduidende verskille tussen hulle gesinne se funksionering beleef nie (vergelyk Tabel 5). In die lig van dié gegewens sou dit veiliger wees om aan te neem dat die werklike verskille tussen die twee groepe se gesinsdinamika kleiner is as wat aangetoon is, of dat daar selfs geen verskille bestaan nie.

Indien daar geen verskille tussen die groepe se gesinsdinamika is nie, is die resultate teenstrydig met die aannames wat daar in die literatuur gemaak word dat 
talle aspekte van pastoriegesinne se funksionering problematies is. Skrywers dui daarop dat die predikant se oormatige betrokkenheid by sy gemeentewerk nadelig inwerk op die affektiewe betrokkenheid tussen die gesinslede. Kruijne (198?:32) beweer dat die vrou die man se afwesigheid uit die huislike kring daaraan wyt dat hy hom van die gesinsintimiteit afsonder en dat die kinders daarteen in opstand kom. Bouma (1979:18) en Mace en Mace (1982:155) meld dat die oorbetrokkenheid wat soms tussen predikante en hulle vroulike gemeentelede vanweë pastoriesorg voorkom, die huweliksverhouding kan benadeel - ' $n$ aspek wat uiteraard implikasies vir die gesinsverhouding sal hê. 'n Ander aspek wat volgens skrywers nadelig kan inwerk op die affektiewe betrokkenheid van die pastorielede is die hedendaagse neiging wat by die predikantsvrou voorkom om haar te distansieer van die tradisionele rol as predikantsvrou. Sy beoefen 'n eie beroep en in haar soeke na 'n eie lewe en identiteit kan haar verbondenheid aan die gesinsisteem verminder (Bouma, 1979:18; Niswander, 1982:162).

In die literatuur is daar ook talle verwysings na die leemtes wat in pastoriegesinne sou wees ten opsigte van die gesinslede se affektiewe responsiwiteit, naamlik die vermoë van die lede om 'n wye spektrum van emosies toepaslik te ervaar. So byvoorbeeld word daar veral verwys na noodemosies (negatiewe emosies) wat in pastoriegesinne sou voorkom. Niswander (1982:168) verwys na die eensaamheid wat by die predikantsvrou voorkom vanweë haar man se werk. Mace en Mace (1980:38) bevind dat die predikant dit moeilik vind om affeksie uit te druk terwyl Faber (198?a:20) en Kruijne (198?:32) beweer dat ouer pastoriekinders soms verset en woede ervaar vanweë die betrokkenheid van die gemeentelede by die gesin. Bratcher $(1984: 88,93)$ meld uit persoonlike ervaring dat die vrou en veral die kinders woede en frustrasie ervaar vanweë die feit dat die kerk te veel van hulle man en vader eis. Miethner en Miethner (1987:411) is verder van mening dat gesinslede van pastoriegesinne dit moeilik vind om hulle spontaneiteit te behou omdat hulle deurentyd in die openbare oog is. In teenstelling met bogenoemde aannames dat pastoriemense veral negatiewe emosies ervaar en dit uitleef, meen Mace en Mace (1982:156) en Niswander (1982:167) dat pastoriemense in ' $n$ groter mate as die gemeenskap, dit moeilik vind om hulle eie negatiewe emosies, in besonder woede en vyandigheid, te erken en te hanteer. Dit kan moontlik in verband gebring word met die beeld van ' $n$ 'nastreef van perfeksie' wat pastorielede dink hulle moet dra omdat hulle vertoonstukke van die gemeenskap is (Grobler, 1988:111)

Daar word ook in die literatuur negatief gerapporteer oor pastoriegesinne se kommunikasie, probleemoplossing en algemene funksionering. Bratcher (1984: 88) stel dat die woede wat die predikantsvrou en haar kinders ervaar vanweë die predikant se besige kerkprogram, die kommunikasie in die pastoriegesin blokkeer en lei tot stram verhoudings. Uiteraard sal die swak kommunikasie ook negatief inwerk op die probleemoplossing van die gesinne. Grobler (1988:112) meld dan 
ook dat talle navorsers en huweliksberaders melding maak van moontlike swak probleemoplossingsvaardighede wat in pastoriegesinne voorkom en wat die algemene gesinsfunksionering benadeel

In die literatuur kon geen spesifieke verwysings aangetref word oor die aard van die gedragskontrole van al die gesinslede wat in pastoriegesinne voorkom nie. Stevenson (1982:82) het egter in sy ondersoek bevind dat die meerderheid pastoriekinders tevrede is met die pastoriestandaarde. Nyberg (soos aangehaal deur Mace \& Mace, 1980:125) meen ook dat die standaarde wat aan pastoriekinders gestel word hulle in 'n begunstigde posisie plaas. Die huidige navorsing se resultate stem dus in hierdie opsig wel ooreen met vorige navorsingsbevindinge.

Die een dimensie op die FAD waarop geen beduidende verskille tussen die twee groepe gesinne gevind is nie, is rolle (Grobler, 1988:204). Die Cronbach alfabetroubaarheidskoëffisiënt van die skaal was onbevredigend, naamlik 0,48. Daar is dus geen verskille tussen die twee groepe gesinne ten opsigte van die wyse waarop rolle toegeken word aan die gesinslede om sekere gesinsfunksies te verrig en die wyse waarop dit gekontroleer word nie.

\subsubsection{FACES III}

Dit blyk uit die resultate dat daar geen beduidende verskil is tussen die twee groepe gesinne ten opsigte van die dimensies kohesie en aanpasbaarheid nie (vergelyk Tabel 6). Daar is dus geen verskille tussen die twee groepe gesinne ten opsigte van die mate van kohesie wat hulle ervaar en hulle vernoë om as gesinne aan te pas by nuwe omstandighede nie.

Die Cronbach alfa-betroubaarheidskoëffisiënt van die subskaal kohesie was goed $(0,87)$, maar die betroubaarheidskoëffisiënt van die aanpasbaarheidsubskaal was onbevredigend $(0,50)$ (Grobler, 1988:180). Die interpretasie van laasgenoemde subskaal se gegewens word dus bemoeilik.

Dit blyk dus dat nieteenstaande die feit dat die pastoriegesinne op talle dimensies van gesinfunksionering, soos aangetoon op die FAD, beter funksioneer as die gesimne van die gemeentelede, daar geen verskil is in hulle belewing van hulle gesinskohesie nie. Dit geld ook moontlik vir hulle vermoë om aan te pas by nuwe omstandighede

Hierdie bevindinge is verrassend, want sowel die kohesie as die aanpasbaarheidsdimensie van FACES III sluit dimensies in wat ooreenstem met dimensies soos gemeet deur sommige van die subskale van die FAD. So byvoorbeeld sluit die kohesie-dimensie van FACES III aspekte in soos emosionele binding en gesinsgrense (Olson, et al., 1985b:19) wat in verband gebring kan word met die 
subskaal affektiewe betrokkenheid van die FAD. Die aanpasbaarheidsdimensie van FACES III sluit aspekte in soos onderhandeling, dissipline, rolle en reëls (Olson, et al., 1985b:19) wat in verband gebring kan word met die volgende subskale van die FAD, naanlik probleemoplossing, rolle en gedragskontrole. Die verskille wat wel voorkom tussen die twee meetinstrumente se resultate is moontlik as gevolg van die feit dat die twee toetse verskillende fasette meet van die dimensies wat ooreenstem. Dit moet verder in gedagte gehou word dat die FAD uit heelwat meer items bestaan as FACES III en daarom moontlik meer sensitief is vir verskille tussen die twee groepe gesinne.

In die literatuur is daar min inligting oor die gesinskohesie en gesinsaanpasbaarheid van pastoriegesinne. Bratcher (1984:94) is van mening dat die predikant se werklas wel daartoe kan lei dat hy geredelik weg kan beweeg uit die gesinskohesie. Mace en Mace (1980:36) daarenteen, het in hulle navorsing bevind dat weens die feit dat die predikant sy beroep vanuit die huis bedryf, dit daartoe lei dat die gesin 'n sterk eenheidsgevoel beleef vanweë die gedeelde geloofsuitlewing en diensbaarheid.

\subsubsection{F-Copes}

Die resultate van F-Copes het aangetoon dat die gesinslede van die gemeentelede hulle funksionering statisties beduidend beter ervaar het as die gesinslede van pastoriegesime ten opsigte van een van die vyf dimensies, naamlik passiewe evaluering (vergelyk Tabel 7). Dit sou impliseer dat daar in die gesinne van gemeentelede minder wrywing voorkom tydens probleemoplossing as in pastoriegesinne. Die Cronbach alfa-betroubaarheidskoëffisiënt van die skaal was egter baie laag $(0,27)$ (Grobler, 1988:192) en die resultate kan daarom betwyfel word.

Die subskale waarop geen verskille aangedui is nie en hulle betroubaarheidskoëffisiënte het die volgende ingesluit: die verkryging van sosiale ondersteuning $(0,73)$, herdefiniëring $(0,55)$, soeke na geestelike ondersteuning $(0,72)$ en die mobilisering van hulp $(0,55)$. Daar is dus nie verskille tussen die twee groepe gesinne tydens probleemoplossing ten opsigte van die volgende aspekte nie: hulle vermoë on aktief betrokke te raak in die verkryging van ondersteuning van familie, vriende en bure; om stresvolle gebeure te herdefinieer ten einde dit hanteerbaar te maak; on geestelike ondersteuning te verkry, en on hulpbronne uit die gemeenskap te kry en die hulp te aanvaar nie.

In die geheel gesien, verskil die resultate van F-Copes met die resultate van die subskaal probleemoplossing van die FAD. Soos vroeër aangetoon, het laasgenoemde subskaal getoon dat die pastoriegesinne se probleemoplossing beduidend beter is as die probleemoplossing van gesinne van gemeentelede. As in ag geneem word dat F-Copes uit 30 vrae bestaan wat spesifiek handel oor effektiewe probleemoplossing en gedragstrategieë wat deur gesinne gebruik word in 
wat handel oor probleemoplossing in die algemeen (Epstein et al., 1983:173), is die verskille tussen die twee meetinstrumente se resultate verstaanbaar.

Uit die resultate van die FAD, FACES III en F-Copes blyk dit dus dat die pastoriegesinne hulle gesinsfunksionering beduidend beter ervaar het as die gemeentelede se gesinslede op ses van die 14 dimensies wat geëvalueer is. Daarteenoor het die gesinslede van die gemeentelede hulle funksionering op slegs een dimensie beter ervaar. Soos aangetoon, word die geldigheid van die resultate egter betwyfel en moet aanvaar word dat daar moontlik geen verskille tussen die groepe se gesinsfunksionering is nie.

Soos aangetoon, verskil die resultate van hierdie navorsing met die aannames wat in die literatuur gemaak word dat pastoriegesinne allerlei probleme ervaar. Grobler (1985:85) se aannames (waarna vroeër verwys is - vergelyk 1.2) dat die literatuur veral op die negatiewe aspekte van pastoriegesinne se interaksie fokus, kan moontlik as 'n verklaring dien. 'n Ander rede kan moontlik wees omdat die ondersoekgroep van die huidige navorsing bestaan het uit lidmate van die drie Afrikaanse kerke, terwyl die literatuur verwys na oorsese navorsingsbevindinge, waarin hoofsaaklik lidmate uit Engelse kerke betrek is.

\section{Gevolgtrekkings}

Dit blyk dat daar nie geldige afleidings gemaak kan word uit die navorsingsbevindinge nie. Daar kan hoogstens gestel word dat daar moontlik geen beduidende verskille is tussen die huweliks- en gesinsfunksionering van pastoriegesinne en gesinne van gemeentelede nie. Soos aangetoon, is die resultate verrassend, want in die literatuur is daar talle verwysings na aspekte van die pastoriegesinne se funksionering wat problematies sou wees

Vanweë die aard en omvang van die populasie wat gebruik is in die navorsing, kan die resultate nie veralgemeen word en beskou word as verteenwoordigend van alle blanke pastoriegesinne of dié van enige ander bevolkingsgroep in die RSA nie. Die grootste leemte betreffende die populasie wat gebruik is, is dat slegs predikante en lidmate uit die drie Afrikaanse kerke betrek is en dat van 'n geleentheidsteekproef gebruik gemaak is 
Tabel 1 Resultate van ENRICH

\begin{tabular}{|l|c|c|c|c|c|}
\hline Dimensie & \multicolumn{2}{|c|}{ Pastoriegesinne } & \multicolumn{2}{|c|}{$\begin{array}{c}\text { Gesinne van } \\
\text { gemeentelede }\end{array}$} & P-waarde \\
\hline & Gem. & St. afwyking & Gem. & St. afwyking & \\
\hline $\begin{array}{l}\text { Distorsie van } \\
\text { ideale }\end{array}$ & 20,95 & 3,47 & 18,93 & 4,85 & $0,010^{*}$ \\
\hline $\begin{array}{l}\text { Huweliks- } \\
\text { bevrediging }\end{array}$ & 41,68 & 6,85 & 38,97 & 7,55 & $0,041^{*}$ \\
\hline $\begin{array}{l}\text { Persoonlikheids- } \\
\text { aangelenthede }\end{array}$ & 39,50 & 7,05 & 36,72 & 7,66 & $0,041^{*}$ \\
\hline Kommunikasie & 35,20 & 6,82 & 33,08 & 6,95 & 0,095 \\
\hline $\begin{array}{l}\text { Konflik- } \\
\text { hantering }\end{array}$ & 39,22 & 7,23 & 35,33 & 6,96 & $0,003^{*}$ \\
\hline $\begin{array}{l}\text { Finansiële } \\
\text { bestuur }\end{array}$ & 39,75 & 6,81 & 39,58 & 6,23 & 0,889 \\
\hline $\begin{array}{l}\text { Vryetyds- } \\
\text { besteding }\end{array}$ & 35,73 & 4,24 & 35,53 & 5,19 & 0,818 \\
\hline $\begin{array}{l}\text { Seksuele } \\
\text { verhouding }\end{array}$ & 44,47 & 5,90 & 40,58 & 7,73 & $0,003^{*}$ \\
\hline $\begin{array}{l}\text { Kinders en } \\
\text { die huwelik }\end{array}$ & 43,13 & 4,64 & 40,28 & 6,64 & $0,006^{*}$ \\
\hline $\begin{array}{l}\text { Familie en } \\
\text { vriende }\end{array}$ & 40,28 & 4,87 & 37,53 & 5,73 & $0,006^{*}$ \\
\hline $\begin{array}{l}\text { rolle } \\
\text { oelykmakie }\end{array}$ & 47,03 & 4,03 & 42,63 & 6,67 & $0,0001^{*}$ \\
\hline pers- 0,05 & 5,40 & 29,75 & 6,25 & $0,061^{*}$ \\
\hline
\end{tabular}

${ }^{*} \mathrm{p}<0,05$ 
Die gesinsdinamika van pastoriegesimme in die drie Afrikaanse kerke

Tabel 2 Resultate van PAIR

\begin{tabular}{|l|c|c|c|c|c|}
\hline Dimensie & \multicolumn{2}{|c|}{ Pastoriegesinne } & \multicolumn{2}{|c|}{$\begin{array}{r}\text { Gesinne van } \\
\text { gemeentelede }\end{array}$} & P-waarde \\
\hline & Gem. & St. afwyking & Gem. & St. afwyking & \\
\hline $\begin{array}{l}\text { Emosionele } \\
\text { intimiteit }\end{array}$ & 26,07 & 4,22 & 23,88 & 4,63 & $0,008^{*}$ \\
\hline $\begin{array}{l}\text { Sosiale } \\
\text { intimiteit }\end{array}$ & 18,90 & 2,91 & 18,57 & 2,61 & 0,510 \\
\hline $\begin{array}{l}\text { Seksuele } \\
\text { intimiteit }\end{array}$ & 25,67 & 3,83 & 23,47 & 4,38 & $0,004^{*}$ \\
\hline $\begin{array}{l}\text { Intellektuele } \\
\text { intimiteit }\end{array}$ & 25,52 & 3,73 & 23,27 & 3,84 & $0,002^{*}$ \\
\hline $\begin{array}{l}\text { Rekreatiewe } \\
\text { intimiteit }\end{array}$ & 23,92 & 3,32 & 23,53 & 3,25 & 0,524 \\
\hline $\begin{array}{l}\text { Sosiale } \\
\text { gewensdheid }\end{array}$ & 24,68 & 4,62 & 22,77 & 4,76 & 0,027 \\
\hline
\end{tabular}

* $p<0,05$

Tabel 3 Resultate van die PCI

\begin{tabular}{|l|c|c|c|c|l|}
\hline Dimensie & \multicolumn{2}{|c|}{ Pastoriegesinne } & \multicolumn{2}{|c|}{$\begin{array}{r}\text { Gesinne van } \\
\text { gemeentelede }\end{array}$} & P-waarde \\
\hline & Gem. & St. afwyking & Gem. & St. afwyking & \\
\hline Kommunikasie & 96,67 & 9,14 & 93,43 & 6,81 & 0,126 \\
\hline
\end{tabular}


Tabel 4 Resultate van die FAD

\begin{tabular}{|c|c|c|c|c|c|}
\hline \multirow[t]{2}{*}{ Dimensie } & \multicolumn{2}{|c|}{ Pastoriegesinne } & \multicolumn{2}{|c|}{$\begin{array}{l}\text { Gesinne van } \\
\text { gemeentelede }\end{array}$} & \multirow[t]{2}{*}{ P-waarde } \\
\hline & Gem. & St. afwyking & Gem. & St. afwyking & \\
\hline $\begin{array}{l}\text { Probleem- } \\
\text { oplossing }\end{array}$ & 10,48 & 2,64 & 11,37 & 2,39 & $0,016^{*}$ \\
\hline Kommunikasie & 16,41 & 3,88 & 17,98 & 3,83 & $0,006^{*}$ \\
\hline Rolle & 20,58 & 3,13 & 20,95 & 3,43 & 0,438 \\
\hline $\begin{array}{l}\text { Affektiewe } \\
\text { responsiwiteit }\end{array}$ & 10,94 & 3,08 & 12,38 & 2,91 & $0,001^{*}$ \\
\hline $\begin{array}{l}\text { Affektiewe } \\
\text { betrokkenheid }\end{array}$ & 13,53 & 3,05 & 14,46 & 2,84 & $0,030^{*}$ \\
\hline $\begin{array}{l}\text { Gedrags- } \\
\text { kontrole }\end{array}$ & 15,24 & 3,43 & 16,37 & 2,96 & $0,015^{*}$ \\
\hline $\begin{array}{l}\text { Algemene } \\
\text { funksionering }\end{array}$ & 21,13 & 4,43 & 23,60 & 4,82 & $0,0003^{*}$ \\
\hline
\end{tabular}

${ }^{*} p<0,05$

NB. Vanweë die wyse waarop die FAD bepunt word, dui 'n lae punt op gunstiger gesinsfunksionering as 'n hoër punt. 
Tabel 5 Resultate van die FAD (Kinders)

\begin{tabular}{|c|c|c|c|c|c|}
\hline \multirow[t]{2}{*}{ Dimensie } & \multicolumn{2}{|c|}{ Pastoriegesinne } & \multicolumn{2}{|c|}{$\begin{array}{l}\text { Gesinne van } \\
\text { gemeentelede }\end{array}$} & \multirow[t]{2}{*}{ P-waarde } \\
\hline & Gem. & St. afwyking & Gem. & St. afwyking & \\
\hline $\begin{array}{l}\text { Probleem- } \\
\text { oplossing }\end{array}$ & 11,54 & 2,69 & 11,56 & 2,48 & 0,98 \\
\hline Kommunikasie & 18,35 & 3,30 & 18,79 & 3,76 & 0,60 \\
\hline Rolle & 20,51 & 2,84 & 21,00 & 3,75 & 0,54 \\
\hline $\begin{array}{l}\text { Affektiewe } \\
\text { responsiwiteit }\end{array}$ & 12,11 & 2,76 & 12,77 & 2,54 & 0,30 \\
\hline $\begin{array}{l}\text { Affektiewe } \\
\text { betrokkenheid }\end{array}$ & 14,00 & 3,25 & 13,97 & 2,87 & 0,97 \\
\hline $\begin{array}{l}\text { Gedrags- } \\
\text { kontrole }\end{array}$ & 16,08 & 3,85 & 16,79 & 2,97 & 0,38 \\
\hline $\begin{array}{l}\text { Algemene } \\
\text { funksionering }\end{array}$ & 22,81 & 4,06 & 23,77 & 5,05 & 0,39 \\
\hline
\end{tabular}


Tabel 6 Resultate van FACES III

\begin{tabular}{|l|c|c|c|c|c|}
\hline \multirow{2}{*}{ Dimensie } & \multicolumn{2}{|c|}{ Pastoriegesinne } & \multicolumn{2}{c|}{$\begin{array}{c}\text { Gesinne van } \\
\text { gemeentelede }\end{array}$} & \multirow{2}{*}{ P-waarde } \\
\hline & Gem. & St. afwyking & Gem. & St. afwyking & \\
\hline Kohesie & 40,70 & 6,68 & 40,24 & 5,45 & 0,602 \\
\hline Aanpashaarheid & 29,48 & 4,33 & 28,91 & 4,88 & 0,391 \\
\hline Totaal & 69,88 & 10,28 & 69,15 & 8,69 & 0,596 \\
\hline
\end{tabular}

Tabel 7 Resultate van F-Copes

\begin{tabular}{|l|c|c|c|c|l|}
\hline \multirow{2}{*}{ Dimensie } & \multicolumn{2}{|c|}{ Pastoriegesinne } & \multicolumn{2}{|c|}{$\begin{array}{r}\text { Gesinne van } \\
\text { gemeentelede }\end{array}$} & P-waarde \\
\hline & Gem. & St. afwyking & Gem. & St. afwyking & \\
\hline $\begin{array}{l}\text { Sosiale } \\
\text { ondersteuning }\end{array}$ & 24,27 & 6,08 & 25,38 & 5,87 & 0,199 \\
\hline Herdefiniëring & 27,53 & 3,34 & 26,43 & 4,51 & 0,058 \\
\hline $\begin{array}{l}\text { Geestelike } \\
\text { ondersteuning }\end{array}$ & 16,22 & 2,77 & 15,90 & 3,40 & 0,489 \\
\hline $\begin{array}{l}\text { Mobilisering } \\
\text { van gesin }\end{array}$ & 13,54 & 3,70 & 13,47 & 3,83 & 0,901 \\
\hline $\begin{array}{l}\text { Passiewe } \\
\text { evaluering }\end{array}$ & 9,76 & 2,83 & 10,79 & 2,52 & $0,009^{*}$ \\
\hline
\end{tabular}

* $p<0,05$ 


\section{Bibliografie}

ANDERSON, R.C. 1985. The Effective Pastor. Chicago : Moody.

BOUMA, M.L. 1979. Divorce in the Parsonage. Minneapolis : Bethany

BRATCHER, E.B. 1984. The Walking-on-water Syndrome. Waco, Texas : Word Books

DOUGLAS, W. 1965. Ministers' Wives. New York: Harper \& Row.

EPSTEIN, N.B., BISHOP, D.S. \& BALDWIN, L.M. 1983. The McMasters Family Assessment Device. Journal of Marital and Family Therapy, 9(2):171-180, April.

FABER, H. 198?(a). Vragen rondom de pastorie. (In Faber, H. \& Kruijne, T., reds. Vragen rond de pastorie. Kampen : Kok. p. 9-25.)

FABER, H. 198?(b). De pastorie - een terrein met conflicten. (In Faber, H. \& Kruijne, T., reds. Vragen rond de pastorie. Kampen : Kok. p. 102-110.)

GROBLER, G.E. 1988. Gesinsdinamika van pastoriegesinne. Potchefstroom : PU vir CHO (MA-verhandeling.)

GUYNES, D.R. 1979. The Pastor and His Family. (In Zimmerman, T.F., ed. And He Gave Pastors. Missouri : Gospel Publishing House. p. 103-130.)

KRUIJNE, T. 198? Familia domini. (In Faber, H. \& Kruijne, T., reds. Vragen rond de pastorie. Kampen : Kok. p. 26-39.)

MACCULLOUGH, D.L. 1983. A Curriculum on Personal Marriage and Family Issues for Students Preparing for Professional Ministries. Michigan : Univ. Microfilms International. (D. Ed. Proefskrif.)

MACE, D. \& MACE, V. 1980. What's Happening to Clergy Marriages? Nashville : Abingdon.

MACE, D. \& MACE, V. 1982. Marriage Enrichment for Clergy Couples. Pastoral Psycho$\log y, 30(3): 151-159$.

McCUBBIN, A., LARSON, A. \& OLSON, D.H. 1985. F-Copes: Family Crisis Oriented Personal Evaluation Scales. (In Olson, D.H. ed. Family Inventories. Univ. of Minnesota, St Paul : Family Social Science. p. 143-159.)

MIETHNER, C. \& MIETHNER, R. 1978. Het predikantshuwelijk: een terrein van konflikten. Praktische Teologie, 5:409-418.

NAVRAN, L. 1967. Communication and Adjustment in Marriage. Family Process, 6:173-184.

NISWANDER, B.J. 1982. Clergy Wives of the New Generation. Pastoral Psychology, 30(3): 160-169, Spring.

ODENDAL, F.J. 1984. Die predikant en uitbranding. Johannesburg : RAU. (M.A.-verhandeling.)

OLSON, D.H., FOURNIER, D.G \& DRUCKMAN, J.M. 1985(a). ENRICH : Enriching \& Nurturing Relationship Issues, Communication \& Happiness. (In Olson, D.H., ed. Family Inventories. Univ. of Minnesota, St Paul : Family Social Science. p. 67-73.)

OLSON, D.H., McCUBBIN, H.I., BARNES, H., LARSEN, A., MUXEN, M. \& WILSON, M. 1985(b). FACES III. (In Olson, D.H., ed. Family Inventories. Univ. of Minnesota, St. Paul : Family Social Science. p. 1-43.)

PRESNELL, W.B. 1977. The Ministers Own Marriage. Pastoral Psychology, 25(4):273-281

REDIGER, G.L. 1982. Coping with Clergy Burnout. Valley Forge : Judson Press.

SCHAEFER, M.T. \& OLSON, D.H. 1981. Assessing Intimacy: The PAIR Inventory Journal of Marital and Family Therapy, 7(1):47-60. Jan.

SMIT, G.J. 1985. Navorsingsmetodes in die gedragswetenskappe. Pretoria : Opvoedkundige uitgewers.

SMUTS, A.J. 1986. Die huwelik en gesinslewe van die predikant. (In Smuts, A.J., red. Praktiese Teologie in Suid-Afrika. Transvaal : N.G. Kerkboekhandel. p. 52-68.)

STEVENSON, R.M. 1982. Children of the Parsonage. Pastoral Psychology, 30(3):179-186

VENTER, C.A. 1988. Die ontwerp en evaluering van 'n psigologiese voorhuwelikse verrykingsprogram. Potchefstroom : PU vir CHO. (D.Phil. Proefskrif.) 